\title{
VIETNAM-CHINA RELATIONS IN 1975-1978: APPROACHED FROM THE PERSPECTIVE OF DISPUTES AND CONFLICTS
}

\section{RELACIONES VIETNAM-CHINA EN 1975-1978: ENFOQUE DESDE LA PERSPECTIVA DE DISPUTAS Y CONFLICTOS}

\author{
Luu Van Quyet ${ }^{1}$ *; Nguyen Thi Anh-Nguyet ${ }^{2}$. \\ 1. University of Social Sciences and Humanities, Vietnam National University, Ho Chi Minh City, Vietnam. \\ luuvanquyet@hcmussh.edu.vn \\ ${ }^{2}$. University of Social Sciences and Humanities, Vietnam National University, Ho Chi Minh City, Vietnam. \\ nguyenthianhnguyet@hcmussh.edu.vn
}

*Correspondencia del Autor: Luu Van Quyet: E-mail: luuvanquyet@hcmussh.edu.vn

\begin{abstract}
Due to geographical factors as well as many different subjective and objective ones, the relations between Vietnam and China have an important position with direct influence and multi-dimensional impact on the development of Vietnam. Historical facts show that whenever Vietnam handles bilateral and multilateral relations with China well, it will create a favorable international environment and ensure security and peace for the development of the country. Since the official establishment of diplomatic relations between the two countries (1949) to 1975, mutual support and assistance have always been at the core. Logically speaking, after 1975, the traditional relations between the two countries should have been further strengthened and developed. However, after the Vietnam War (1975) and under the impact of many subjective and objective factors, increasingly serious conflicts arose in the Vietnam - China relations, leading to the termination of diplomatic relations between the two countries in 1978. Of which there are three major disputes regarding the issues of Chinese-Vietnamese people; Democratic Kampuchea; and the East Sea and terrestrial border.
\end{abstract}

Keywords: dispute; conflict; relations; Vietnam-China; 1975-1978.

Cómo citar:

Van Quyet, Luu; Anh-Nguyet, Nguyen Thi. (2021). VIETNAM-CHINA RELATIONS IN 1975-1978: APPROACHED FROM THE PERSPECTIVE OF DISPUTES AND CONFLICTS. Revista de Investigaciones Universidad del Quindio, 33(1), 154-167. https://doi.org/10.33975/riuq.vol33n1.499 


\section{RESUMEN}

Debido a factores geográficos, así como a muchos diferentes subjetivos y objetivos, las relaciones entre Vietnam y China tienen una posición importante con influencia directa e impacto multidimensional en el desarrollo de Vietnam. Los hechos históricos muestran que siempre que Vietnam maneje bien las relaciones bilaterales y multilaterales con China, creará un entorno internacional favorable y garantizará la seguridad y la paz para el desarrollo del país. Desde el establecimiento oficial de relaciones diplomáticas entre los dos países (1949) hasta 1975, el apoyo y la asistencia mutuos siempre han sido fundamentales. Lógicamente hablando, después de 1975, las relaciones tradicionales entre los dos países deberían haberse fortalecido y desarrollado aún más. Sin embargo, luego de la Guerra de Vietnam (1975) y bajo el impacto de muchos factores subjetivos y objetivos, surgieron conflictos cada vez más serios en las relaciones Vietnam-China, que llevaron a la terminación de las relaciones diplomáticas entre los dos países en 1978. De los cuales hay tres disputas importantes sobre los problemas del pueblo chino-vietnamita; Kampuchea Democrática; y el Mar del Este y la frontera terrestre.

Palabras clave: disputa; conflict; relaciones; Vietnam-China; 1975-1978.

\section{INTRODUCTION}

Throughout 25 years of development (19501975), mutual support and assistance remained the spine in the relations between Vietnam and China. Although during this period, under the impact of many factors, the relations between the two countries had certain rifts, in general, Vietnam was still one of the neighboring countries with which China has the best relations at that time. In 1945, the birth of the Democratic Republic of Vietnam was yet to be recognized by any countries, and Vietnam itself was fighting the resistance war against the French. Not so long after this establishment, in 1950, the People's Republic of China was the first country in the world to establish diplomatic relations with the Democratic Republic of Vietnam (now the Socialist Republic of Vietnam), marking a great diplomatic victory for Vietnam. Although the two countries did not sign any formal alliance agreements, during Vietnam's two resistance wars against the French (1945-1954) and the US (1954-1975), China provided huge material and mental supports to Vietnam. In contrast, Vietnam had always been supporting China's foreign policy. Logically speaking, the traditional relations between the two countries should be further strengthened and developed; however, since mid-1975, after Vietnam was completely liberated, under the impact of international and regional situation as well as the foreign policy of each country, Vietnam-China relations fractured with frequent tensions leading to confrontations and conflicts which caused the two countries to sever ties in 1978.

There have been many studies published by Vietnamese and international scholars on the relations between Vietnam and China with various analyses and interpretations, such as: Hun Sen (1991), Ramses Amer (1991), Pham, Q. M. (2015), Luu, V. L. (1998), W. Burchett (1986), William Shawcross (1979), Craig Etcheson (2006), Boraden Nhem (2009), Jon Swain (1996), Nguyen, V. T. (2017), Gary R. Hess (1994), Qiang Zhai 2000, Ramses Amer (1994), Karl D. Jackson (2014), Nguyen, T. M. H. (2014), Luu, V. Q. (2016), Le, T. D. (2016), etc. However, the published works focus largely on the relations between the countries from the establishment of relations (1950) until the end of the resistance war of Vietnamese people against the US in 1975, or the relations between the two countries since their normalization of ties (1991) to date. For different reasons, research on the relations between Vietnam 
and China in 1975-1978 so far has many "gaps" without having many systematic research works that approach the relations from the perspective of disputes and conflicts. These are the issues that we will focus on clarifying in this study. At the same time, we also make initial comments and reviews; thereby, this article also draws attention to lessons learned for the relations between the two countries in present.

\section{METHODS}

To carry out this study, we used methods of historical research, logical research and international relations study to supplement the findings of our predecessors by presenting a comprehensive and insightful view of the international and regional context, the foreign policy of each country after the Vietnam War; as well as the disputes and conflicts in Vietnam-China relations in 1975-1978. In addition, the article also uses interdisciplinary/transdisciplinary methods, such as: analysis, statistics, comparison, etc. to observe and assess research issues in a more scientific and objective way.

\section{HISTORICAL CONTEXT AND FOREIGN POLICY OF VIETNAM AND CHINAAFTER THE VIETNAM WAR}

In 1975, Vietnam emerged victorious in the resistance war against the US and proceeded to rebuilding the country as the world situation was having profound changes. After the Vietnam War, the US withdrew its troops from continental SoutheastAsia, and world politics entered the "postVietnam" period. Powerhouses made important adjustments in their foreign policies. The position and strength of the US declined, while Western Europe and Japan rose to compete with the US, and there was a growing trend of independence from the US in the Western world. The US started to adjust its strategy, reduced its external commitments, promoted peace with its main rivals, and focused on solving domestic problems to consolidate its position in the capitalism world. However, since it did not want Southeast Asia to fall under the influence of the Soviet Union and China, the US still sought to influence this region. The Soviet Union gained a strategic balance with the US in terms of arms control, leading to a period of reconciliation between major countries: USSoviet Union; Western Europe - Soviet Union; US - China; Western Europe and Japan with China. The goodwill and efforts of the countries at the top of each pole to reduce the tensions were shown in high-level meetings between the Soviet Union and the US. In late July 1975, a summit was held between heads of state and heads of governments of European countries in Helsinki. The push by the Soviet Union for the signing of the Helsinki Convention marked a new development in relations between countries of different socio-political regimes, and ended 30 years of confrontation in Europe (HCMC-SHA, 2018, p. 105).

In the context of volatile international situation, after the country's reunification in terms of politics (1976), in order to enlist favorable international conditions for the socialistoriented development of the country, the focus of Vietnamese foreign policy was determined as "enlist favorable international conditions to quickly heal the wounds of wars, recover and develop the economy, develop culture, science and technology, ..., continue to stand shoulder to shoulder with other socialist countries and all the peoples of the world to fight for peace, national independence, democracy and socialism" (Communist Party of Vietnam, 1997, p.178). For socialist countries (including China), Vietnam continues to emphasize the importance of strengthening solidarity and friendly cooperation: "[...] we work to strengthen friendship, solidarity and economic cooperation with the Soviet Union, China and other brotherly socialist countries" (Communist Party of Vietnam, 2004, p.362).

Regarding China, after 1975, Vietnam remained stuck in the US-China-Soviet Union triangle, however the correlation between those three countries in this period changed profoundly, which was highlighted by the conflict between China, Vietnam and Cambodia. In the past, 
Vietnam-China relations and Vietnam - Soviet Union relations had disagreements, but with the US as mutual rival, the other two countries were still allies of Vietnam (Pham, 2015). However, since 1972, when China and the US shook hands, it was the sign of a shift in international relations. At that time, although the conflicts between capitalism and socialism persisted, the influences were reduced. Chinese leaders perceived that the immediate danger at that time was not the US, but the Soviet Union, so they sought American support in the struggle against the Soviet Union (Luu, 2016, p.48).

From the second half of the 1970s, China underwent many important changes, including the death of Chairman Mao Zedong in September 1976, followed by the arrest of key figures in the "cultural revolution". In 1978, the "four modernizations" reform plan of Deng Xiaoping, consisting of industry, agriculture, science and technology, and national defense opened a new period of development for the People's Republic of China (Luu, 1998). In that context, China took into account domestic and foreign affairs for the purpose of internal stability and external expansion.

In China's Southeast Asia policy, Vietnam played a very important role. China needed Vietnam to be a country that is "not strong, divided, not independent and dependent on China" (Karl D. Jackson, 2014, p.41). However, in 1975, Vietnam was completely liberated. The victory of Vietnam destroyed the strategic plans of China in the region and drastically changed the forces in Southeast Asia. At that time, the US had to withdraw from continental Southeast Asia, creating a "power vacuum" and favorable conditions for the Soviet Union to expand its influence in Southeast Asia (Pham, 2015). China was not happy with that and was concerned that the influence of the Vietnamese revolution will undermine the influence of China in the region, especially in the Indochinese Peninsula (Nayan Chanda, 1986, pp.22-25); at the same time, events such as the reception of President R. Nixon in China (1972), the Chinese invasion of Hoang Sa (Paracel Islands) (1974), the border conflicts initiated by China, etc (Luu, 2016). further pushed Vietnam away from Chinese influence. Therefore, China chose Cambodia, more specifically the Khmer Rouge government as the springboard to prevent and destroy Vietnam.

Continuing to see the Soviet Union as the number one enemy, China always tried to turn Vietnam against the Soviet Union. While Vietnam still maintained its foreign policy of independence, self-reliant and close relations with the Soviet Union, China gradually proceeded to openly oppose Vietnam. In its anti-Vietnam policy, China tried to enlist the support of the US and other countries. From seeing each other as enemies, China turned to get closer to and normalize diplomatic relations with the US (HCMC-SHA, 2018). Under the influence of many factors as well as the foreign policy of each country, from 1975 to 1978 , the relations between Vietnam and China had many disagreements and tensions which led to conflicts in 1979. Of which there are three major disputes regarding the issues of ChineseVietnamese people; Democratic Kampuchea; and the East Sea and terrestrial border.

\section{DISPUTES AND CONFLICTS IN VIETNAM - CHINA RELATIONS}

\section{Dispute regarding Chinese Vietnamese people}

The immigration of Chinese people (or Hoa people) to Vietnam as well as to other countries in Southeast Asia is a complicated and long process that happened in many phases in many forms, from being sporadic and spontaneous to being massive with large scale. Due to geographical characteristics compared to other countries in the region, Chinese people migrated to Vietnam quite early. Soldiers and troops aside, the fact that Chinese people migrated to Vietnam and settled here was common after the civil wars in China. In the flow of history, along with changes in Chinese history, the number of Chinese people coming to Vietnam gradually increased. Over centuries, 
Chinese people came to all three regions of North, Central and South Vietnam with population of 1.2 to 2 million (Luu, et. al, 2020).

Regulations applied to Hoa people in Vietnam during the times of Vietnamese feudal dynasties were no different from residents of other ethnic communities (they enjoy civil rights and are treated the same as Vietnamese citizens). Since the beginning of the $19^{\text {th }}$ century, children born from marriages between Vietnamese citizens and Hoa people are considered Vietnamese citizens and fully enjoy political rights. During the war, Hoa people also stood side by side with Vietnamese people to overcome the hardships. In 1955, according to the agreement between the Vietnamese Labor Party and the Chinese Communist Party, "Chinese people residing in North Vietnam must be placed under the leadership of the Communist Party of Vietnam and gradually naturalized as Vietnamese citizens" (Ramses Amer, 1991, p.8), to enjoy the same rights as Vietnamese citizens and to voluntarily accept Vietnamese citizenship. In the South, during the period of 1955-1956, the Republic of Vietnam government also introduced laws and regulations for Chinese Vietnamese. Accordingly, all children born from marriages between Chinese and Vietnamese citizens are considered Vietnamese citizens, all Chinese born in Vietnam automatically become Vietnamese citizens (including those who were born in the time before) (Ramses Amer, 1991, p.10). During the resistance war of Vietnam against the US (1954-1975), there was no disagreements between Vietnam and China regarding Hoa people in Vietnam. However, after the reunification of Vietnam, Hoa people in Vietnam became a controversial issue which led to tensions between the two countries.

After 1975, the Government of Vietnam continued to comply with the agreement signed by both countries in 1955 regarding Hoa people in Vietnam. According to the agreement, all Hoa people in Vietnam (whether in the North or the South) are Vietnamese, and no longer have Chinese nationality. However, since late 1976, China changed its policy for "overseas Chinese".
During the "Great Cultural Revolution" (from 1960s to 1970s), Chinese people repatriating to China were suspected by the government to be wealthy and were discriminated against, but since the beginning of 1977, China looked forward to receiving supports from oversea Chinese (including those residing in Vietnam) for country development (Nguyen, 2014). Thus, China considered all Hoa people in Vietnam as Chinese nationals; accused Vietnam of not implementing the agreements that both countries signed in mid$1950 \mathrm{~s}$, not ensuring the voluntary selection of nationality of Hoa people, forcing Hoa people to accept Vietnamese citizenship, etc.

In April 1978, Vietnam proceeded to renovate the capitalist and private industry and trade in the South. Although the renovation was not deliberately aimed at the Hoa people community or any individual communities, but due to historical factors, most capitalists in the South were of Chinese origin, thus became the main subject of this reform (People's Daily, 1978). China considered the industry and trade reforms in some major cities in South Vietnam as a public challenge to China's newly-announced policy to protect overseas Chinese, so it appealed to policy of Vietnam (People's Daily, 1978). During this period, the Chinese mass media began to spread arguments provoking national psychology and calling on Hoa people to give up Vietnamese citizenship and repatriate. Allegations about an inevitable war between Vietnam and China, how Chinese people in Vietnam will be affected, etc. were also spread in the Chinese Vietnamese community, causing them to be confused and panic-stricken. Affected by the propaganda campaign of China, many young Hoa people in Sai Gon - Cho Lon gathered to cross the border; tens of thousands of Hoa people in Ho Chi Minh City closed their shops and moved their homes. The wave of Hoa people leaving Vietnam for China and other countries increased rapidly (Nguyen, 2014).

On April 30, 1978, Liao Cheng, Chairman of Office for Overseas Chinese Affairs (under the State Council of China) openly said that "Chinese 
people in Vietnam are massively repatriating", starting the "exodus of Hoa people". In order to draw the attention from the international public, China set up reception stations along the border of the two countries and asked Vietnam to allow Chinese ships to dock in ports of Hai Phong and Ho Chi Minh City to pick up repatriating Hoa people in 3 months (Party Central Office, 1986). By the end of 1978, there were about 200,000 Hoa people leaving Vietnam for China (Ramses Amer, 1994, pp. 360-361).

Along with accusations against Vietnam regarding the issue of Hoa people, using the excuse of "solving many problems for Hoa people", from late 1975, China stopped its non-refundable aid, terminated loans by the end of 1977, and also withdrew its experts from Vinh Phuc textile factory in May 1978 (Stephen J. Morris, 1999, p.29).. On May 12 and May 30, 1978, using the reason of dealing with problems regarding accommodation and work for Hoa people returning to China from Vietnam, China sent to the Government of Vietnam two diplomatic notes announcing the decision to cancel 72 projects previously agreed by both countries (Ramses Amer, 1994, pp. 360-361). On July 3, 1978, China announced the termination of all economic and technical assistance, and withdrew all Chinese experts who were working in Vietnam back to China (Ramses Amer, 1994, p. 32). From 1976, China had been reducing and by 1978 completely cut off the aid of about 500 million USD for equipment and 300 million USD per year for goods and supplies for Vietnam, including 340 thousand tons of food, 430 thousand tons of petroleum, 30 million meters of cloths and 15 thousand tons of cotton, 140 thousand tons of fertilizer, 150 thousand tons of cement, 200 thousand tons of bituminous coal, etc (Party Central Office, 1986). Explaining the aid termination, in addition to having a huge financial burden in arranging work and accommodation for repatriated Chinese people, China also stated that "Vietnam is increasingly and seriously anti-China... so that we are forced to cut off all economic and technical aid for Vietnam as well as to send our experts in Vietnam back home (Vietnam Institute for Military History, 1988, p.12).

Not only unilaterally cutting off the aid agreed by both countries, on June 17, 1978, China ordered Vietnamese consulates in Kunming, Guangzhou and Nanning to relocate to their home country (Stephen J. Morris, 1999).. On July 12, 1978, China closed the border with Vietnam, trapping tens of thousands of Hoa people who wanted to go to China. By the time the departure of Hoa people was rampant, China made the condition that those who want to return to China must apply for a repatriation permit from the Chinese Embassy in Hanoi as well as an exit passport issued by the Vietnamese government, and claimed to accept only Chinese people who are being mistreated by the Vietnamese Government, and definitely not to accept Vietnamese of Chinese origin, or Chinese with Vietnamese citizenship (Ramses Amer, 1994, p. 32).

Given the complexity of the matter, many negotiations on the repatriation of Chineseorigin people in Vietnam between the two countries in 1978 took place but did not yield results due to different views of the two parties. China believed that Vietnam mistreated and deported Hoa residents, as well as not allowed Hoa people in Vietnam to freely choose their nationality (Nguyen, 2014). Meanwhile, Vietnam asserted its stance that all Hoa people in Vietnam are Vietnamese. On September 1, 1978, Vietnam issued a 4-argument statement: (1) The Vietnamese government calls on the Hoa people to stay in Vietnam, where they can rest assure to live and work. China had to stop using these people to interfere in the internal affairs of Vietnam; (2) Hoa people who want to leave Vietnam will be allowed to leave after completing exit procedures. Vietnam is willing to discuss with China specific events regarding those people; (3) Hoa people in Southern Vietnam who want to come back to China will be provided with all favorable conditions to leave Vietnam; (4) Those who leave for China are not allowed to return to Vietnam. In case of having justifiable reasons, 
the Government of Vietnam will consider to let them return. China is not to sponsor illegal reimmigration (Ramses Amer, 1991, pp. 33-35). It can be said that the issue of Hoa people is one of the reasons that increase tensions in VietnamChina relations.

\section{Dispute over the issue of Democratic Kampuchea}

Southeast Asia is a particularly important geographical region for China. In addition to its richness and abundance of resources, with its geographic location at the intersection of important maritime routes, Southeast Asia is seen as a very important region for China's ambitions to increase its influence and expand its power to the Indo-Pacific, Eurasian continent and Australian continent, and trade with the Middle East and Africa at the same time (HCMC-SHA, 2019). In China's Southeast Asia policy, Vietnam plays a very important role. China needs Vietnam to be a country that is "not strong, divided, not independent and dependent on China" (Karl D. Jackson, 2014, p.41). However, in 1975, Vietnam was completely liberated, which spoiled China's strategic plans for the region. In the situation of "not being able to keep Vietnam in its orbit" (Gilbert Padoul, 1986), Chinese leaders used economic and military aid to carry out the plan of capturing and turning Cambodia into a "dyke" for the establishment of its influence in this region. Cambodia was chosen to "play a central role in China's strategy and to encircle Vietnam in Southeast Asia" (Military Library 1980, p.9). In order to isolate Vietnam, China emphasized the argument that "the ambition of Hanoi will threaten not only China's interests in the Indochinese Peninsula, but also the position of "non-communist" countries in ASEAN" (Banh, 1986, p.83).

From mid-1975, Chinese rice-carrying ships began to arrive at Kompongsom Port. In 1975, in addition to 61,000 tons of rice, China also provided the Khmer Rouge with 30,000 tons of fuel and lubricants, 3,000 tons of kerosene, 3 diesel generators, 300 trucks, 9,000 sleepers,
1,000 railway equipment units, 250 tons of pesticide, 1 ton, 8 million pickaxes, 2,600 tons of plow blades, 237,000 shovels, 60 tons of medicines, 20,000 bicycles, 3,300 tons of clothes, 200 sewing machines (Nguyen, 2014). In addition to economic support, China also increased the military aid given to the Khmer Rouge. In February 1976, a Chinese military delegation led by the Deputy Chief of Staff of the People's Liberation Army arrived in Phnom Penh and signed a secret agreement on military cooperation with Minister of Defense of the Democratic Kampuchea. Accordingly, China pledged to transfer to the Khmer Rouge equipment for 1 anti-aircraft artillery regiment, 1 radar regiment, 1 battalion; equipment for military airports, patrol ships and speedboats for the Navy, equipment for 1 tank regiment, 1 communications regiment and 3 artillery regiments (Luu, 2018, pp.109-110). From 1975 to 1978, China supplied to Democratic Kampuchea cannons, mortars, bazookas, heavy and medium machine guns, weapons of all kinds, vehicles and gasoline enough to equip an army of 200,000 soldiers. China also gave Cambodia a huge amount of money, and at the same time sent about 10,000 military advisors and experts to assist and train the army for Pol Pot (New Era Magazine, 2005). With that help, the Cambodian army grew rapidly in quantity (from 6 divisions in April 1975 to 11 divisions in 1976 and by December 1978, there were 26 divisions, most of which were stationed on the border with Vietnam) (Nguyen, et. Al, 1996, pp.108-109.

In the 1975-1978 period, the Cambodian factor had an important impact on Vietnam-China relations. Due to geographical conditions and historical circumstances, Vietnam and Cambodia had always been allies who stand side by side of each other throughout the two resistance wars against the French and the US. However, shortly after the resistance war against the US concluded on the Indochinese Peninsula, the conflicts between the Democratic Kampuchea and the Socialist Republic of Vietnam became exacerbated, and the Pol Pot Ieng Sary forces constantly caused aggression on the southwest border. In May 1975, Pol Pot - Ieng 
Sari forces attacked Tay Ninh and Phu Quoc Island and killed hundreds of people on Tho Chu Island of Vietnam, thereby seriously threatening the security and sovereignty of Vietnam. According to statistics of Military Statistics Board - Ministry of Defense of Vietnam, from May 1975 to the end of 1975, Pol Pot caused 110 conflicts and encroached 20 demarcation points. The number of conflicts in 1976 was 280, and 1.850 in 1977, a six-time increase from 1976 (HCMC-SHA, 2018).

On December 23, 1978, Pol Pot deployed 10 regiments to launch attacks across the southern border with the main goal of capturing Tay Ninh town and plotting a large-scale attack to Ho Chi Minh City. On December 25, 1978, the Vietnam People's Army launched a strategic counterattack, smashing Pol Pot-Ieng Sari's invasion of Tay Ninh town. At the request of the Kampuchea United Front for National Salvation led by Mr. Heng Samrin, and for the peace and stability of Indochina, Vietnam fulfilled its international duty by closely working with armed forces of the KUFNS to conduct a counterattack. On January 7, 1979, forces of Vietnam and KUFNS led by Heng Samrin attacked and liberated Phnom Penh. On January 10, 1979, the People's Republic of Cambodia was established (Le, 2016, pp.63-64). Vietnam's act of bringing troops to Cambodia faced fierce international response and was condemned as "invasion" and "territorial violation" of a sovereign state which threatened world peace and security. The civil war and political conflicts between opposite factions in Cambodia, mainly between the Cambodian People's Party of Hunsen, the government of the Democratic Kampuchea of the Khmer Rouge, the royalist party Funcinpec of Norodom Sihanouk, the Khmer People's National Liberation Front (KPNLF) of former Prime Minister Son Sann, etc. broke out throughout the 1980s, making it extremely difficult for finding a solution for peace of this country. The political situation in Cambodia became a complex and controversial international issue in the following period (Hoang, 2019, p.6).

In 1975-1976, as military forces of Vietnam and the Democratic Kampuchea clashed with each other, China tried to pose itself as a mediator to maintain its influence and coerce Vietnam to its side to fight against the Soviet Union, thus reduce Soviet influence in Vietnam and Southeast Asia (Pham, 2015). In the visit to China, Vietnam's delegation, led by Le Duan, First Secretary of the Central Executive Committee of the Workers' Party, sent its thanks to the communist party and the government of China for helping Vietnamese people in the resistance war against the US, and discussed measures to further strengthen ties between the two countries. The Chinese government pledged to provide the aid promised to Vietnam before 1975 to build 111 projects. In October 1976, China provided Vietnam with a number of defensive weapons. In 1977, China lended 900,000 tons of food to Vietnam (MFAV, 2015, p.310).

However, from 1977, as the relations between Vietnam and Cambodia became bitter and finally came to an end, the Vietnam-China relations also turned worse and more complicated. The reason was that China considered Cambodia an important link to create Chinese influence in Southeast Asia, therefore Vietnam's act turned the plans of China upside down. On the other hand, since it had failed to take Vietnam out of the influence of the Soviet Union, and Vietnam maintained its independent and self-reliant foreign policy and remained close to the Soviet Union, China gradually made going against Vietnam public. On July 30, 1977, Chinese Foreign Minister Huang Hua said: "We support Cambodia's antiimperialist position and will not be able to sit and watch any interference with Cambodian sovereignty or territorial cravings by the socialist empire. We will support Cambodia in this struggle and take actions to protect Cambodia's territory and national sovereignty with all possible help" (Luu, 1998, p.112-113).

The relations between the Democratic Kampuchea and China was increasingly promoted and tightened through many long-term, high-level visits between the two. After Pol Pot's visit to China in May 1975, Khieu Samphan as Prime Minister of Democratic Kampuchea visited 
Beijing (August 1975), conducted talks with the Chinese leadership and signed an Agreement on Economic Cooperation (HCMC-SHA, 2018). Accordingly, China promised to provide to Cambodia non-refundable aid of $\$ 1$ billion within five years, including economic and military aid. As calculated by AFP news agency, this amount accounts for more than half of all Chinese aid to foreign countries (Nguyen, et, al 1996, p.108). On the same occasion, Khieu Samphan also signed a statement to condemn Soviet "hegemony" (HCMC-SHA, 2019). In September 1977, during the talk with Chinese leaders, Pol Pot affirmed China's tremendous military help in increasing his forces from 7 to 23 divisions in 1975 and building three branches of armed forces as well as military units. The total number of Chinesebranded weapons amounted to 450 big guns, 294 tanks, 1,200 vehicles of all kinds, and 42 aircraft. China also sent thousands of military advisors to Cambodia (Nguyen, et. al 1996). In December 1977, China's then-Deputy Prime Minister Wang Dongxing visited Cambodia and went to areas near the border with Vietnam, and later declared: "no forces can impede the friendship between China and Cambodia. The two countries will forever be comrades" (Military Library, 1980). Between 1975 and 1978, while China significantly reduced aid to developing countries and completely terminated aid to Vietnam and Laos altogether, it focused on increasing aid to the Khmer Rouge, which accounted for more than half of all Chinese aid to foreign countries (Le, 2007).

On Vietnam's side, in an effort to resolve the border issue with Cambodia through negotiations for peace, the Government of Vietnam still asked China to help with the settlement and wished to improve the situation with Cambodia through the collaboration with China (HCMC-SHA, 2018). In order to mend the rifts in the relations with China and balance the Vietnam-Soviet Union and Vietnam-China relations, in November 1977, First Secretary Le Duan visited China. In their talks, Le Duan requested Chinese leaders to ask the Democratic Kampuchea to accept a solution to the conflict on the Southwestern border, but this request was refused by China. In January 1978, Prime Minister Pham Van Dong asked other brotherly countries to help resolve the VietnamCambodia conflict (Military Library, 1980).

On its part, Chinese documents from 1977 always said that "Vietnam is a henchman of the Soviet Union who has the ambition of invading Cambodia, Laos and taking over the entire Southeast Asia to establish regional hegemony. Therefore, we must fight against Vietnamese revisionists and we must fight big. In Asia Vietnam is considered a small powerhouse that invaded Cambodia and drove Chinese people away" (Nguyen, 2014). On July 12, 1978, People's Daily - the official newspaper of the Chinese Communist Party publicly accused Vietnam of "trying to annex Cambodia into an Indochinese Federation led by Vietnam" (Military Library, 1980).

As Pol Pot intensified military activity on the border with Vietnam, China also stepped up its anti-Vietnam campaign. In its anti-Vietnam policy, China always tried to enlist the support from the U.S. as well as other countries in the region. Facing China's increasing support to the Khmer Rouge and strategic cooperation with the U.S., Vietnam "inched closer" to the Soviet Union. On June 25, 1978, Vietnam joined the Soviet-led Council of Mutual Economic Assistance (SEV); on November 3, 1978, Vietnam signed with the Soviet Union a Treaty of Friendship and Cooperation valid for 25 years and 5 accompanying agreements including a defense agreement: "in case a country becomes the target of aggression or intimidation, two members will discuss with each other to eliminate the threat and together take measures to protect peace and security of the two countries" (HCMC-SHA, 2019). Reacting to the signing of the Treaty by Vietnam and the Soviet Union, China immediately conducted three major activities: (1) Strengthening the alliance with the Khmer Rouge; (2) Enticing Asean countries into an anti-Vietnam front; (3) Normalizing relations with the U.S. 
One day after Vietnam and the Soviet Union signed the Treaty, on November 4, 1978, Wang Dongxing, a member of the Politburo of Chinese Communist Party went to Phnom Penh and clearly expressed China's support for Democratic Kampuchea's policy, advised the state to initiate a long-term resistance using guerrilla warfare and promised that China would wholeheartedly support the Democratic Kampuchea. Pol Pot then went on the radio to praise China's "unconditional support" for Phnom Penh in the fight against Vietnam (Luu, 1998, p.121).

For Asean countries, after 1975, the US withdrew its troops from Southeast Asia and the SEATO military bloc disintegrated. In February 1976, the Treaty of Amity and Cooperation in Southeast Asia was signed to build peace, friendship and lasting cooperation in the region. ASEAN countries in turn established diplomatic relations with Vietnam, creating a friendly and peaceful atmosphere in Southeast Asia, and contributing to the "reconciliation" of hostilities that were mainly created by the competition of major countries outside the region. However, the "Cambodian problem" caused the breakdown of dialogues between Vietnam and ASEAN countries (Hoang, 2019, p.6). In November 1978, Dang Xiaoping visited ASEAN countries and made no secret of his intention to use military measures to deal with Vietnam. The attitude of ASEAN countries to Vietnam thus changed a lot. They all believed that Vietnam-Cambodia and Vietnam-China conflicts would threaten the stability and peace of the region. Vietnam's "tilt" toward the Soviet Union with the Soviet - Vietnam Comprehensive Treaty of Friendship and Cooperation (1978) caused ASEAN countries who already feared the "communist wave" to think that Vietnam would become a "threat" and that they need to "stay closer" to China (Hoang, 2019, p.6). At the request of Deng Xiaoping, Thailand agreed for Chinese aircraft to transit at the country on the journey to Cambodia and back, thereby opening up a trans-Thai trail and turned this country into a safety strategic checkpoint of China in Southeast Asia (Nayan Chanda 1998, p.394). Asean countries, fearing that the war could spread to Thailand, threatening this country's security and dragging them into a regional conflict, demanded Vietnam to withdraw its troops from Cambodia and isolated Vietnam (Vu, 2017, p. 197).

In late December, 1978, China came into contact with the US, and on December 15, 1978, China and the US issued a joint statement announcing their normalization of relations. On January 28, 1979, Deng Xiaoping visited the United States to enlist American support in the act of war in order to "teach Vietnam a proper lesson" (Luu, 1998, p. 122).

In January 1979, Vietnam sent troops to Cambodia and overthrew the Pol Pot regime. China made its protest and repeatedly had statements and comments that accused Vietnam of invading and occupying Phnom Penh, called on Cambodian citizens to prepared for a long-term fight and promised to provide comprehensive support to the Democratic Kampuchea (Nguyen, 2014). In addition, Chinese Deputy Minister of Foreign Affairs Han Renlong and Minister of Defense Jing Xiao flew to Thailand many times to discuss the provision of equipment, weapon and support for the Khmer Rouge (HCMC-SHA, 2019). China also presented to the Security Council a draft resolution calling on Vietnam to withdraw its troops and other countries to terminate aid to Vietnam. China refused to recognize the People's Republic of Cambodia and actively provide financial aid for three parties: FUNCINPEC (the National United Front for an Independent, Neutral, Peaceful and Cooperative Cambodia); KPNLF (the Khmer People's National Liberation Front) and PDK (the Party of Democratic Kampuchea) to go to the war against the People's Republic of Cambodia (HCMC-SHA, 2018). Commenting on the event, researcher Ramesh Thakur wrote: "Beijing saw that event not as the liberation of the Cambodian people, but as the completion of Vietnam's pursuit from 1930 of an Indochina Federation dominated by Hanoi" (Ramesh Thakur 1980, p.69). 
As such, the Cambodian issue further caused the relations between Vietnam and China in 19751978 period to be more complex with profound disagreements. The rifts in Vietnam-China relations deepened and gradually shifted to a tense state.

\section{East Sea and terrestial border conflicts}

As a vast body of water surrounding Vietnam, China, Malaysia, Singapore, Brunei, Philippines, Indonesia Thailand and Cambodia, the East Sea is strategically important with abundant resources. The 1887 treaty between France and China specified the offshore boundary along the northeastern border at $108^{\circ} 3^{\prime} 18^{\prime}$. During the decades of Vietnamese resistance war against the French and the US, Vietnam and China had no complicated issues regarding the Gulf of Tonkin. In 1973, Vietnam noticed China of its intention to sign contracts with foreign countries for oil and gas exploration in the Gulf of Tonkin, and requested a negotiation to determined the territorial waters in this area. China accepted to conduct negotiations, but refused to allow third-party foreign companies to participate in the exploitation of resources here (HCMC-SHA, 2019). However, China later signed contracts with the Union of oil companies of the US to conduct seismic surveys off the Gulf of Tonkin, then sealed contracts with foreign companies regarding the lots bordering disputed areas and conducted military exercises here. In negotiations to resolve disputes, Vietnam has always affirmed the legality of the border line through two conventions in 1887 and 1895 signed between the French and the Qing Dynasty (China), demanding China to maintain the status quo of the border established by history.

The Geneva Accords on Indochina stipulated that Vietnam was temporarily divided into two regions along the $17^{\text {th }}$ parallel. The southern sea including Hoang Sa (Paracel Islands) and Truong Sa (Spratly Islands) was under the jurisdiction of the Republic of Vietnam. Taking advantage of the transfer of right to manage the islands between the French troops and the Saigon army, China occupied the eastern part of Hoang $\mathrm{Sa}$ (including two large islands of Phu Lam and Linh Con). In early 1974, as the US power in Indochina was weakened and the government of Saigon fell into chaos, China deployed troops to occupy Hoang Sa (called Xisha in Chinese), the territory of Vietnam which was then under the management of the US-sponsored Saigon government. On January 11, 1974, China declared that Xisha Islands (i.e. Hoang Sa) and Nansha Islands (i.e. Truong Sa) as Chinese territory. In the context that the war was not over, and the country was still divided, Vietnam only required the concerned parties to resolve the dispute by negotiation in the spirit of equality, mutual respect and friendliness (Luu, 2016, p. 50).

On September 9, 1975, delegates of the Provisional Revolutionary Government of the Republic of South Vietnam attending the World Meteorological Conference in Colombo declared Vietnam's sovereignty over Hoang Sa (MFAV, 1984, p.17) and asked the world meteorological organization to continue registering Vietnamese meteorological station in the islands. In the visit to China of the delegation of Vietnamese communist party and government led by Le Duan in September 1975, Vietnam presented its claim of sovereignty over Hoang Sa and Truong Sa Islands. In the meeting on September 24, 1975, Deng Xiaoping said that China had sufficient evidence to assert that Hoang Sa and Truong Sa had long been Chinese territory, but the dispute must be addressed through negotiation, consultation, and peaceful manner. Deng Xiaoping also said that both parties could negotiate and discuss later (HCMC-SHA, 2019). On May 12, 1977, the Government of Vietnam issued a declaration on territorial waters, contiguous zone, 200-mile exclusive economic zone and continental shelf of Vietnam, including Hoang Sa and Truong Sa Islands. On July 30, 1977, Chinese Minister of Foreign Affairs HuangHua announced: "When the time comes, we will reclaim the entire Nansha (Truong Sa) Islands without having to negotiate anything" (D. Stepanov, 1980). Each time China commits border violations and armed provocation 
on Vietnam's border, the Government and the Ministry of Foreign Affairs of Vietnam repeatedly issued statements and sent diplomatic notes of protest to China's Ministry of Foreign Affairs.

Along with sea and island disputes and violations, from 1975, the situation of VietnamChina border became tense. China often caused troubles, invaded territory, unilaterally removed or destroyed border landmarks, and even kidnapped and killed Vietnamese citizens in Cao Bang - Lang Son. In March 1977, Vietnam and China conducted negotiations on the Cao Lang Guangxi border issue. The Vietnamese delegation requested to discuss measures to end national border violations and restore the historical border, while the Chinese delegation only wanted to discuss measures to prevent disputes, maintain the status quo and wait for the governments of both countries to negotiate a settlement.

From 1978, the extent of China's territorial violations and armed provocation on the border of Vietnam became increasingly serious. In July 1978, when China closed its border with Vietnam, more fierce clashes between the two countries took place. According to Vietnamese statistics, the number of armed violations of China into Vietnam in 1978 was 583, in January and the first weeks of February 1979 this number reached 230 cases (MFAV, 1979, p.4). On January 1, 1979, representatives of the Department of Chinese Affairs under Ministry of Foreign Affairs of Vietnam met with representatives of Chinese embassy in Vietnam to give a memorandum which affirmed that "the Government and people of Vietnam always respect the friendship between Vietnamese and Chinese people, and wish for the border areas between the two countries to be friendly areas". But just over a month later, despite careful preparations both domestically and internationally, on February 17, 1979, China launched an attack along Vietnam's northern border. Although China claimed this was only a counterattack for self-defense, in essence, "this is a full-scale invasion by regular forces of most of the Chinese military zones" (MFAV, 1979, p.91). The war brought by China to Vietnam left many consequences for both countries as well as the region and broke the relations between the two countries.

\section{CONCLUSION}

From 1975, a unified Vietnam with independent and self-reliant foreign policy had been seen as an obstacle to China's anti-Soviet strategy and its ambition to spread its influence to Southeast Asia. Moreover, due to differences in perceptions and stances between the two countries regarding some issues before 1975, by mid-1976, Vietnam had gradually then decisively leaned towards the Soviet Union, and China then took punitive measures against Vietnam, including: cutting off aid, withdrawing experts, propagandizing the issue of "Chinese refugees", enticing Chinese people in Vietnam to return to China; supporting the Khmer Rouge to attack the southwestern border of Vietnam; causing armed provocative events with increasing levels of conflict at the sea, islands and northern terrestial borders of Vietnam, then sending 60 thousand soldiers to attack Vietnam along the northern border line on February 12, 1979 in order to "teach Vietnam a lesson", etc. These things pushed the relations between the countries in 1975-1978 down to the lowest in the history of relations between the two, which lasted until the end of the 80 s.

Since the late 1980s, as the international situation had new changes, each country and both countries began the process of bringing their relations back to normal. Currently, in the global trend, Vietnam and China both implement the policy of mutilateralization and diversification in foreign relations. The relations between Vietnam and China are developing day by day in many fields. The historical lessons of the diplomatic relations between the two countries during this period therefore are still valid. 


\section{REFERENCES}

1. Baum, J. (1986). "Peking Snubs Hanoi: no talks tall Vietnam leaves Cambodia" The Christion Science Monitor Inter national Edition, Sept, pp.1-7.

2. Bonavia, David (1919). "Changing the Course of History" Far Eastern Economic Review, Mar. 2, pp. 8-10.

3. Bonavia, David (1979). "Peking Learns its own Lesson" Far Eastern Economic Review, Mar. 30, pp. $12-13$.

4. Bonavia, David (1979). "Sowing the seeds of a Bigger War" Far Eastern Economic Review, Mar. 9, pp. $12-13$.

5. Communist Party of Vietnam (1997). Political Report of the Party's Central Executive Committee at the $4^{\text {th }}$ National Congress, Truth Publishing House, Hanoi.

6. Communist Party of Vietnam (2004). Documents of the Party, full collection, Vol. 36, National Political Publishing House, Hanoi.

7. D. Stepanov (1980). China's expansion on the sea, International Relations Publishing House, Hanoi.

8. Gary R. Hess (1994). "The Unending War: Historians and the Vietnam War", Diplomatic History, 18, pp.239-264

9. Gilbert Padoul (1986). Post-Mao Zedong foreign policy of China, Translation, archived at Military Library.

10. HCMC-SHA (Ho Chi Minh City Science and History Association) (2018). Some issues about the War to Protect the Homeland in the Southwest Border of Vietnam, National University Publishing House, Ho Chi Minh City.

11. HCMC-SHA (Ho Chi Minh City Science and History Association) (2019). Some issues about the War to Protect the Homeland in the Northern Border of Vietnam, National University Publishing House, Ho Chi Minh City.

12. Hoang, H. H. (2019). The Cambodian Problem in Vietnam - Asean Relation (1979-1995), Journal of Science, Vol 48, No. 1b, pp.5-13.

13. Karl D. Jackson (2014). Cambodia, 1975-1978, Rendezvous with Death, Princeton University Press.

14. Kobelev, E.V (1986). Cambodia: From disaster to revival, Progress Publishing House.

15. Le, K. (1984). A failure of Beijing expansionists, People's Army Publishing House, Hanoi.

16. Le, P. H. (2007). History of international Relations after the Second world war. National University of Education Publishing House, Ho Chi Minh City.

17. Le, T. D. (2016). Border relations between Vietnam and Cambodia in the 1975-1978 period, Journal of Historical Studies, No. 6.

18. Luu, V. L. (1998). 50 years of Vietnamese diplomacy (1945-1995), vol.2, People's Public Security Publishing House, Hanoi.

19. Luu, V. Q, et. al (2020). The Imprint of Hoa People (Chinese) in the Establishment and Development of Commercial Hubs in Southern Vietnam (in the $17^{\text {th }}-19^{\text {th }}$ centure), International Journal of Psychosocial Rehabilitation, Vol. 24, Issue 10, pp.4705-4718.

20. Luu, V. Q. (2016). Impact of China-U.S. deferment on China's aid policy to Vietnamese people's resistence in 1972 and beyond, Jornal Science \& Technology Develoment, Vol 19, No.X4, pp.4558.

21. MFAV (Ministry of Foreign Affairs of Vietnam) (1979). Memorandum of Ministry of Foreign Affairs of Vietnam, People's Newspaper (Bao Nhan dan), February 16, 1979.

22. MFAV (Ministry of Foreign Affairs of Vietnam) (1979). The truth about Vietnam - China relations over the past 30 years, Truth Publishing House, Hanoi.

23. MFAV (Ministry of Foreign Affairs of Vietnam) (1984). Hoang Sa Islands and Truong Sa Islands: Vietnam's Territory, Social Science Publishing House, Hanoi.

24. MFAV (Ministry of Foreign Affairs of Vietnam) (2015). Vietnam's Diplomacy in 1945-2000, National Politics -Truth Publishing House, Hanoi.

25. Military Library (1980). The China-Vietnam conflict. Special Edition (Translation). Archived at Military Library.

26. Nayan Chada (1979). "The Aganising Choice” Far Eastern Economic Review, Mar. 18.

27. Nayan Chanda (1986). Brother Enemy: The War after the War. New York: Harcourt Brace 
Jovanovich.

28. New Times Magazine, No. 6, December 2005.

29. Ngo, V. L. (2005). Some questions about the relationship between diplomacy and socialist reform work in the decade after the liberation of the South, New Era Magazine, No. 6.

30. Nguyen, H. T., et. al (1996). The truth about Chinese military dispatches and the Vietnam-China relations, Da Nang Publishing House, Danang.

31. Nguyen, T. M. H. (2014). Conflict, Conflict in Vietnam-China relations and the border war in February 1979. Nghe An Culture, http://www.vanhoanghean.com.vn/

32. Nguyen, T. M. H. (2014). The Cambodian issue in the Sino-Vietnamese War in 1979. Nghe An Culture, http://www.vanhoanghean.com.vn

33. Party Central Office (1986). Socio-economic development orientations and tasks in 1981-1985, submitted to the 11th Conference of the Central Executive Committee of the Communist Party of Vietnam, Session IV, Party Central Archives Office.

34. Party Central Office (1986). Summary document of the Party's works (1975-1985), Party Central Archives Department.

35. Peng Muran (1986). Chinese decision-making in the Punitive War on Vietnam, Archived at Military Library, p.83.

36. People's Army Newspaper, issue on May 11, 1979.

37. People's Newspaper, February 16, 1979.

38. Pham, Q. M. (2015). Relations between Vietnam - Soviet Union - China triangle during the resistance war against the US (1954-1975), National University Publishing House, Hanoi.

39. Qiang Zhai (2000). China and the Vietnam Wars, 1950-1975, The University of North Carolina Press, Chapel Hill and London, p.64.

40. Ramesh Thakur (1980). Coexistence to Conflict: Hanoi-Moscow-Pekings Relations and The China-Vietnam War, The Australian Outlook, Volume 34, No. 1.

41. Ramses Amer (1991). Chinese people in Vietnam and China-Vietnam relations, Kuals Lumpur (Translation). Archived at the Library of the Government's Border Board.

42. Ramses Amer (1994). "Sino-Vietnameses Normalization in the Light of Crisis of the late 1970s", In: the "Pacific Affairs", Vol.67, N3, University of British Columbia Canada.

43. Stephen J. M. (1999). The Soviet-Chinese-Vietnamse triangle in the 1970s: the view from Moscow, Cold war international history project, Washington, D.C, p.29

44. Viet, L. (2019). Sino-Vietnamese War in 1979: Causes and goals. www.mghiencuuquocte

45. Vietnam Institute for Military History (1988). China's Department of International Affairs Research, No. 2, (Translation). Archived at the Information and Documentation Department, Vietnam Institute for Military History.

46. Vu V. T \& Dang C. T. (2017). US-China relations in the first half of the $21^{\text {st }}$ century: A new type of relations between powerhouses? National Politics -Truth Publishing House, Hanoi.

47. Vu, D. N. (2017). Vietnamese revolution on the international stage: History and Issues, National Politics -Truth Publishing House

48. W. Burchett (1986). The China-Cambodia-Vietnam triangle, Information and Reasoning Publishing House, Hanoi. 